\title{
Nitrous oxide emissions from a beech forest floor measured by eddy covariance and soil enclosure techniques
}

\author{
M. Pihlatie ${ }^{1}$, J. Rinne ${ }^{1}$, P. Ambus ${ }^{2}$, K. Pilegaard ${ }^{2}$, J. R. Dorsey ${ }^{3, *}$, Ü. Rannik ${ }^{1}$, T. Markkanen ${ }^{4}$, S. Launiainen ${ }^{1}$, and \\ T. Vesala ${ }^{1}$ \\ ${ }^{1}$ Department of Physical Sciences, University of Helsinki, Finland \\ ${ }^{2}$ Biosystems Department, Ris $\varnothing$ National Laboratory, Roskilde, Denmark \\ ${ }^{3}$ Department of Earth Sciences, University of Manchester, UK \\ ${ }^{4}$ Department of Micrometeorology, University of Bayreuth, Germany \\ *now at: CNR - ESPM - Ecosystem science, University of California, Berkeley, USA
}

Received: 17 March 2005 - Published in Biogeosciences Discussions: 20 May 2005

Revised: 22 September 2005 - Accepted: 22 November 2005 - Published: 8 December 2005

\begin{abstract}
Spring time nitrous oxide $\left(\mathrm{N}_{2} \mathrm{O}\right)$ emissions from an old beech (Fagus sylvatica L.) forest were measured with eddy covariance (EC) and chamber techniques. The aim was to obtain information on the spatial and temporal variability in $\mathrm{N}_{2} \mathrm{O}$ emissions and link the emissions to soil environmental parameters. Mean $\mathrm{N}_{2} \mathrm{O}$ fluxes over the five week measurement period were $5.6 \pm 1.1,10 \pm 1$ and $16 \pm 11 \mu \mathrm{g} \mathrm{N} \mathrm{m}^{-2} \mathrm{~h}^{-1}$ from EC, automatic chamber and manual chambers, respectively. High temporal variability characterized the EC fluxes in the trunk-space. To reduce this variability, resulting mostly from random uncertainty due to measuring fluxes close to the detection limit, we averaged the fluxes over one day periods. The variability in the chamber measurements was much smaller and dominated by high small scale spatial variability. The highest emissions measured by the EC method occurred during the first week of May when the trees were leafing and the soil moisture content was at its highest. If chamber techniques are used to estimate ecosystem level $\mathrm{N}_{2} \mathrm{O}$ emissions from forest soils, placement of the chambers should be considered carefully to cover the spatial variability in the soil $\mathrm{N}_{2} \mathrm{O}$ emissions. The EC technique, applied in this study, is a promising alternative tool to measure ecosystem level $\mathrm{N}_{2} \mathrm{O}$ fluxes in forest ecosystems. To our knowledge, this is the first study to demonstrate that the EC technique can be used to measure $\mathrm{N}_{2} \mathrm{O}$ fluxes in the trunk-space of a forest.
\end{abstract}

\section{Introduction}

Microbial activity in soil ecosystems is the major source of nitrous oxide $\left(\mathrm{N}_{2} \mathrm{O}\right)$ to the atmosphere. Nitrous oxide acts as a greenhouse gas in the troposphere accounting for approx-

Correspondence to: M. Pihlatie

(mari.pihlatie@helsinki.fi) imately $6 \%$ of the radiative forcing of all greenhouse gases. In addition, $\mathrm{N}_{2} \mathrm{O}$ takes part in ozone depleting reactions in the stratosphere. An atmospheric life time of 120 years and a global warming potential of about 300 times higher than that of carbon dioxide, in 100-years time horizon, makes $\mathrm{N}_{2} \mathrm{O}$ an important factor in the global climate system (IPCC, 2001).

Forest soils are a source of $\mathrm{N}_{2} \mathrm{O}$ to the atmosphere but the source strengths of different forests are still uncertain. Annual emissions range from near 0 to $20 \mathrm{~kg}$ of $\mathrm{N}_{2} \mathrm{O}-\mathrm{N}$ per hectare, depending on atmospheric $\mathrm{N}$ deposition, forest type and management practices (Schmidt et al., 1988; Tietema et al., 1991; Papen and Butterbach-Bahl, 1999; Bowden et al., 2000; Beier et al., 2001). Several soil physical, chemical and biological factors and their interactions control microbial $\mathrm{N}_{2} \mathrm{O}$ production in the soil. In forest ecosystems the key factors regulating $\mathrm{N}_{2} \mathrm{O}$ emissions are soil moisture, temperature, and nitrogen availability (Butterbach-Bahl et al., 2002; Schindlbacher et al., 2004; Papen and ButterbachBahl, 1999). Increase in soil moisture, temperature or the availability of mineral nitrogen usually stimulates soil microbial processes and consequently $\mathrm{N}_{2} \mathrm{O}$ production.

High spatial and temporal variability characterizes $\mathrm{N}_{2} \mathrm{O}$ emissions from different ecosystems and makes it challenging to reliably estimate the $\mathrm{N}_{2} \mathrm{O}$ emissions on ecosystem level (Ambus and Christensen, 1995; Christensen et al., 1996; Weitz et al., 1999; Ishizuka et al., 2005). This spatial and temporal variability results from small scale differences or changes in the substrates for microbial $\mathrm{N}_{2} \mathrm{O}$ production, such as nitrate, ammonium and organic material contents. In forest ecosystems one source for the variability in $\mathrm{N}_{2} \mathrm{O}$ emissions is the death and decay of fine roots, a process that increases the availability of nitrogen and carbon substrates for the soil micro-organisms (Silver et al., 2005).

The most commonly used technique in $\mathrm{N}_{2} \mathrm{O}$ emission measurements is the closed chamber technique (see

(C) 2005 Author(s). This work is licensed under a Creative Commons License. 
e.g. Papen and Butterbach-Bahl, 1999; Schulte-Bisping and Brumme, 2003). It has the advantages of being relatively easy and inexpensive to use, and it is especially appropriate when soil fluxes are related to the chemical and microbiological factors of the soil in small scale. However, soil chambers are prone to problems such as: possible modification of the flow at the soil-air interface, un-representativeness of the sampling places, and the disturbance of the chamber collars to the soil ecosystem (see e.g. Hutchinson and Livingston, 2001; Pumpanen et al., 2003; Savage and Davidson, 2003). As opposed to the chamber techniques the micrometeorological techniques do not disturb the soil and the fluxes are integrated over a large source area giving a tool for ecosystem level flux measurement. Similarly to the automated chamber measurements the micrometeorological techniques are often operated continuously and hence give information on the temporal variability in the fluxes.

The most direct micrometeorological flux measurement method, the eddy covariance (EC) method, relies on the measurement of variations in vertical wind velocity and trace gas concentration above the source surface with high time resolution (see e.g. Baldocchi, 2003). The EC method is routinely used to measure fluxes of for example carbon dioxide $\left(\mathrm{CO}_{2}\right)$ and water vapor $\left(\mathrm{H}_{2} \mathrm{O}\right)$ above vegetation canopies. It has recently also been adopted for trunk-space measurements of $\mathrm{CO}_{2}, \mathrm{H}_{2} \mathrm{O}$ and $\mathrm{NO}$ fluxes (e.g. Yang et al., 1999; Constantin et al., 1999; Wilson and Meyers, 2001; Rummel et al., 2002; Tang et al., 2005). The sub-canopy measurements require steady state conditions, no sources or sinks between the soil surface and measurement height, and an extended level and horizontally homogeneous upwind fetch (Baldocchi and Meyers, 1991). According to Wilson and Meyers (2001) the variability of measured fluxes on short time-scales $(\sim 1 \mathrm{~h})$ results mostly from statistical random errors due to single measurement point and finite sampling period. However, the long-term ( $>1$ day) variation of the fluxes is less prone to these sampling errors.

Simultaneous EC and chamber measurements of $\mathrm{N}_{2} \mathrm{O}$ fluxes have been conducted on agricultural grassland ecosystems, but data from forest ecosystems is lacking (Smith et al., 1994; Christensen et al., 1996; Laville et al., 1997). The spatial variability of $\mathrm{N}_{2} \mathrm{O}$ emissions from forest ecosystems has only been addressed using chamber techniques (Ambus and Christensen, 1995; Butterbach-Bahl et al., 2002). To our knowledge, this is the first study to compare EC and chamber techniques to measure $\mathrm{N}_{2} \mathrm{O}$ fluxes from a forest floor. The aims of this study were 1) to obtain information on the spatial and temporal variability of $\mathrm{N}_{2} \mathrm{O}$ fluxes, and 2) to link the variability in $\mathrm{N}_{2} \mathrm{O}$ emissions to soil environmental parameters.

The measurements took place during the five week field measurement campaign FOXNOTE (Forest Oxidized Nitrogen Transport Experiment). The experiment was part of the EU project NOFRETETE and took place in an old beech ( $\mathrm{Fa}$ gus sylvatica L.) forest in Sorø, Denmark. During the five week campaign $\mathrm{N}_{2} \mathrm{O}$ emissions were measured with manual and automatic chambers, and using the $\mathrm{EC}$ technique in the trunk-space of the beech forest. To link the $\mathrm{N}_{2} \mathrm{O}$ emissions to environmental parameters, soil extractable mineral nitrogen content, soil temperature and soil moisture, and meteorological parameters were also measured.

\section{Materials and methods}

\subsection{Site description}

The experiment was conducted in Denmark in the forest Lille Bøgeskov (Small Beech-forest) near Sorø on the island of Zealand $\left(55^{\circ} 29^{\prime} \mathrm{N}, 11^{\circ} 39^{\prime} \mathrm{E}\right)$. The forest is located in a flat terrain and covers about 1.5 square kilometers of mainly of 82 year old beech (Fagus sylvatica L.) trees. Approximately $200 \mathrm{~m}$ on the south-east of the measurement site there is a small plantation of Norway spruce (Picea abies (L.) Karsten). The campaign period extended from 2 May to 5 June 2003 . The average tree height of beech trees is $25 \mathrm{~m}$ and trunk diameter is $38 \mathrm{~cm}$, and the stand density is about 283 stems ha $^{-1}$ (Pilegaard et al., 2003). Total Leaf Area Index above the measurement height was $5.2 \mathrm{~m}^{2} \mathrm{~m}^{-2}$ on 26-27 May 2003, as measured with an LAI 2000 Plant Canopy Analyzer (LI-COR, Lincoln, Nebraska, USA). The soil in the area is either Alfisol or Mollisol according to the American Soil Taxonomy system, and it has a pH of 4 to 5 and a $10-40 \mathrm{~cm}$ deep organic layer with a $\mathrm{C} / \mathrm{N}$ ratio of about 20 in the upper organic layers and about 10 in the lower mineral layers. A detailed description of the site is given in Pilegaard et al. (2003), and the placing of soil chambers, EC measurement system and soil sampling places are shown in Fig. 1.

\subsection{Eddy covariance measurement system}

The eddy covariance (EC) measurement system consisted of an ultrasonic 3-D anemometer (Solent 1012, Gill Ltd., Lymington, Hampshire, England) and a tunable diode laser (TDL) trace gas analyzer (TGA100, Campbell Scientific Inc., Logan, Utah, USA). The TDL system consists of a temperature and current controlled single mode diode laser, tuned to an infra red $\mathrm{N}_{2} \mathrm{O}$ absorption band, mounted in a liquid nitrogen dewar. Concentration measurement is achieved by passing the infra red laser beam through an absorption tube to the sample and reference cells. The reference gas $\left(2000 \mathrm{ppm} \mathrm{N}_{2} \mathrm{O}\right.$ ) is drawn through the reference cell under same temperature and pressure conditions as the sample air in the sample cell.

The sonic anemometer and the inlet of the TDL were situated below the forest canopy at $3.0 \mathrm{~m}$ height (Fig. 2). The sample air was drawn to the TDL analyzer with a Busch rotary-vane pump (RB0021-L) via a diffusive dryer (PD1000, Perma pure Inc.) to remove excess water vapor 


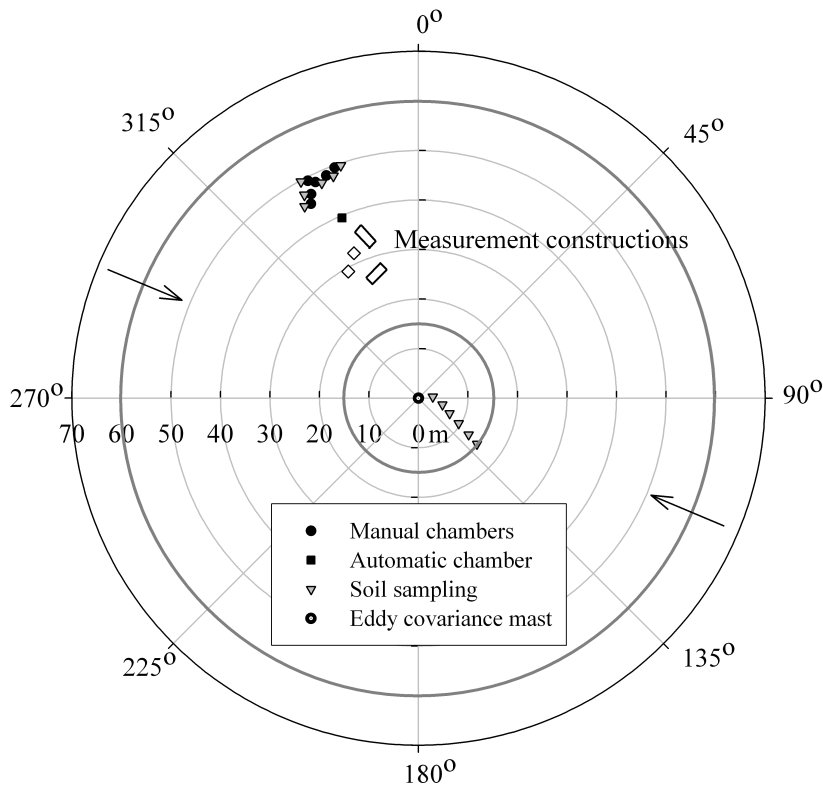

Fig. 1. Site map of the beech forest Lille Bøgeskov. Black open circle in the origin represents the eddy covariance mast, black circles the manual chambers, black square the automatic chamber, grey triangles the soil sampling places, and open squares the two measurement towers and measurement buildings at the site. Grey lines around the site represent the footprint areas from which $50 \%$ (at $15 \mathrm{~m}$ ) and $85 \%$ (at $60 \mathrm{~m}$ ) of the $\mathrm{N}_{2} \mathrm{O}$ fluxes originate. Arrows indicate prevailing wind directions during the campaign.

that could infer the analysis. Total flow rate of the air entering the dryer was $171 \mathrm{~min}^{-1}$, from which the sample flow was $141 \mathrm{~min}^{-1}$ and the purge flow was $31 \mathrm{~min}^{-1}$, adjusted with a needle valve and a flow meter attached to the bottom of the dryer, respectively. Sample air leaving the dryer was directed to the TDL analyzer via a $10 \mathrm{~m}$ long Teflon tubing with i.d. of $4 \mathrm{~mm}$. The total volume of the inlet system was approximately 0.241 and that of the sample cell 0.481 . The residence time in the sample cell was approximately $0.1 \mathrm{~s}$. During the measurement period, pressure inside the sample cells was kept at approximately 70 mbar and the measurements were conducted at $10 \mathrm{~Hz}$ frequency. The TDL was calibrated once during the measurement period using zero and span (290.3 ppb $\mathrm{N}_{2} \mathrm{O}$ ) calibration gases.

Laurila et al. (2005) used the same system for measuring methane emissions from a municipal landfill. They found the measurement system to have a good high frequency response with half power frequency of $1.6 \mathrm{~Hz}$ and high frequency loss of $6 \%$ above an open area at the measurement height of $2.5 \mathrm{~m}$.

\subsection{Eddy covariance data processing}

The vertical flux of the $\mathrm{N}_{2} \mathrm{O}$ is calculated as the covariance between the vertical wind velocity $(w)$ and the $\mathrm{N}_{2} \mathrm{O}$ concentration. Averaging time for flux calculations was $30 \mathrm{~min}$ and

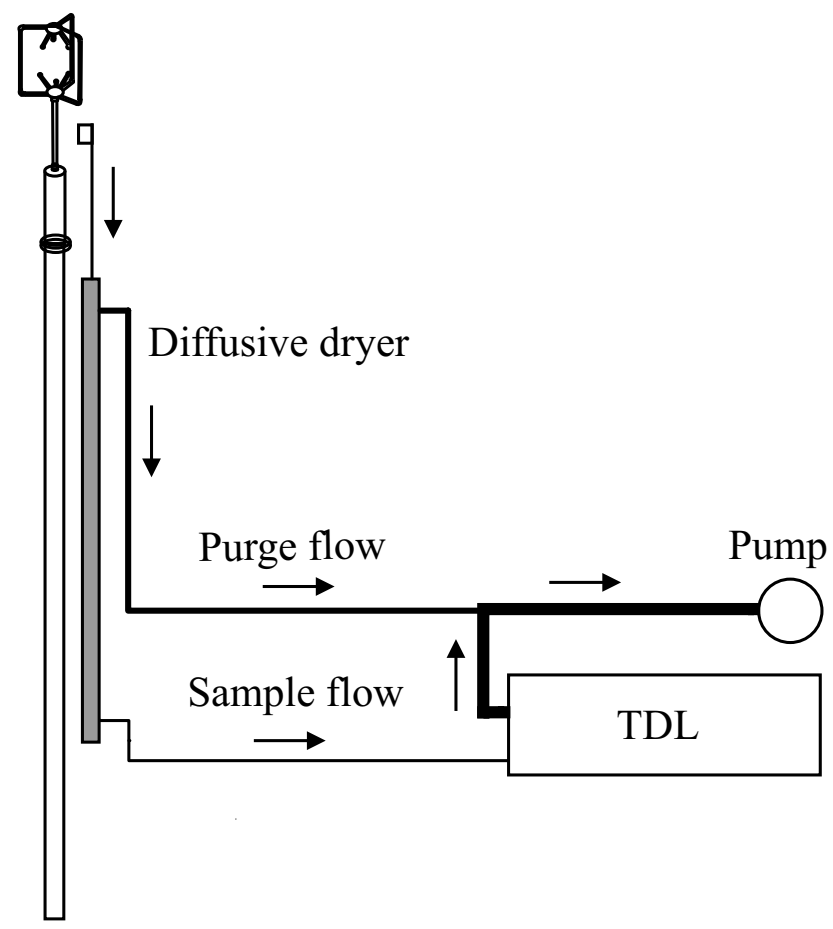

Fig. 2. Schematic presentation of the eddy covariance (EC) measurement system with 3-D anemometer and a TDL analyzer. Arrows represent the sample and purge air flow directions in the measurement system and the line thickness expresses the inner diameter of the tubing.

all signals were linearly de-trended prior to flux calculations. The lag-time due the residence time of the sample air in the inlet tubing was determined using covariance function between the vertical wind speed and $\mathrm{N}_{2} \mathrm{O}$ concentration signals. However, as the fluxes measured were close to the detection limit of the system, the lag-time was not obtained separately for each half-hourly averaging period. Instead, an average lag-time for the whole period was calculated by averaging covariance functions from longer periods. The lag-time obtained by this method was two seconds and did not change markedly during the measurements. The lag-time obtained was in the range of the one calculated using the sample flow and volumes of the inlet tubing and the sample cell. The longer averages of the covariance function as well as the autocovariance function of the $\mathrm{N}_{2} \mathrm{O}$ concentration behaved in a similar way than reported by Wienhold et al. (1994).

Since trunk-space EC measurements lack a standard criterion for removing low turbulence periods, such as $\mathrm{u}^{*}$ criterion used for above canopy measurements, we filtered the flux data using a criterion for standard deviation of vertical wind speed. All the measurements with standard deviation of vertical wind speed less than $0.07 \mathrm{~m} \mathrm{~s}^{-1}$ were discarded from further analysis. In these situations the EC-method is not applicable as the turbulent mixing is not sufficient. This threshold limit was found suitable for trunk-space EC 
measurements of carbon dioxide at a pine forest site in Finland (Launiainen et al., 2005) and also at the site of this study (data not shown). The data filtering removed approximately $78 \%$ of the night time (22:00-08:00) data points and about $35 \%$ of the day time (08:00-22:00) data points. During the first two weeks of the campaign less data was lost than during the rest of the campaign when on occasional days almost all of the night time data was removed due to low turbulence.

The Lagrangian stochastic trajectory calculation procedure (Thomson, 1987) was used for estimation of flux footprint functions. The simulations were performed releasing $3 \times 10^{4}$ particles from the ground and followed until the upwind distance from the observation point accounted over $99 \%$ of the total flux. A one and half order closure model for neutral stratification by Massman and Weil (1999) was used to parameterize flow statistics within the canopy. A detailed description of the model used is given by Markkanen et al. (2003) and Rannik et al. (2000).

According to the footprint analysis, the area contributing $85 \%$ to the EC flux lies within $60 \mathrm{~m}$ from the EC mast, and the area contributing 50\% to the eddy flux lies within 15 meters around the measurement mast (Fig. 1).

\subsection{Flux detection limit of the eddy covariance system}

The detection limit of the EC measurement system depends on the signal noise of the TDL instrument $\left(\sigma_{c}\right)$ and the standard deviation of vertical wind speed $\left(\sigma_{w}\right)$ at the observation level. Flux detection limit $\left(\sigma_{x}\right)$ was calculated as

$\sigma_{x}=\frac{\sigma_{w} \sigma_{c}}{\sqrt{T f}}$

where $\mathrm{T}$ is the averaging time and $\mathrm{f}$ the measurement frequency. The noise level of TDL for $\mathrm{N}_{2} \mathrm{O}\left(\sigma_{c}\right)$ has been estimated to be $1 \mathrm{ppb}$, and the typical standard deviation of vertical wind speed $\left(\sigma_{w}\right)$ below forest canopy at $3 \mathrm{~m}$ height is about $0.15 \mathrm{~m} \mathrm{~s}^{-1}$. For a $30 \mathrm{~min}$ averaging period with $10 \mathrm{~Hz}$ measurement frequency the detection limit of the $\mathrm{N}_{2} \mathrm{O}$ flux $\left(\sigma_{x}\right)$ at Sorø measurement site is $4.6 \mu \mathrm{g} \mathrm{N} \mathrm{m}^{-2} \mathrm{~h}^{-1}$. For daily mean values of $\mathrm{N}_{2} \mathrm{O}$ emissions, the detection limit decreases to approximately $1 \mu \mathrm{g} \mathrm{N} \mathrm{m}^{-2} \mathrm{~h}^{-1}$.

\subsection{Soil enclosure measurements}

Enclosure measurements were conducted with six manual static chambers and one automatic static chamber located north to north-west from the EC mast (Fig. 1). The manual static chamber collars, made of $30 \mathrm{~cm}$ diameter and $15 \mathrm{~cm}$ long PVC pipes, were pushed ca. $5 \mathrm{~cm}$ depth into the soil giving a headspace volume of $7.1 \mathrm{dm}^{3}$. At the time of gas sampling the chamber collars were closed with Perspex lids equipped with butyl rubber stoppers. Four gas samples were taken at 20 min intervals from the headspace by syringe and needle through the stopper. The manual chamber measurements were conducted on weekly basis. Automatic chamber measurements were conducted with an automated gas sampling system (UIT, Dresden, Germany). A $10 \mathrm{~cm}$ high stainless steel collar covering an area of $0.7 \times 0.7 \mathrm{~m}^{2}$ was pushed $5 \mathrm{~cm}$ into the soil. During a chamber measurement the collar was sealed by a $10 \mathrm{~cm}$ high chamber box sliding automatically on the collar. During one enclosure three gas samples were taken at $40 \mathrm{~min}$ intervals. The automatic chamber was operated in three hour intervals during 7 to 14 May, and thereafter twice a day. All chamber collars had been in place at least 16 weeks prior to the campaign. The gas samples from both manual and automatic chamber systems were injected to $3.5 \mathrm{ml}$ pre-evacuated glass vials (Venojects ${ }^{\circledR}$ ) until analysis by a Shimadzu gas chromatograph 14B (Shimadzu, Kyoto, Japan) equipped with an Electron Capture Detector, and an automatic headspace sampler (Mikrolab, Århus, Denmark). The detection limit for the chamber measurements during the measurement period was estimated as $2 \mu \mathrm{g} \mathrm{N} \mathrm{m}^{-2} \mathrm{~h}^{-1}$.

\subsection{Soil measurements}

Soil samples were collected on daily basis from 6 to 14 May and thereafter twice a week. The samples were collected from the top $10 \mathrm{~cm}$ layer with a $2.5 \mathrm{~cm}$ diameter soil core; six samples from the area close to manual soil chambers, and six samples from an area adjacent to the EC measurement system (Fig. 1). In total 12 soil samples per each sampling day were obtained and frozen on the day of sampling. The soils were melted at $+4^{\circ} \mathrm{C}$ and sampled for gravimetric soil moisture $\left(105^{\circ} \mathrm{C} ; 24 \mathrm{~h}\right)$ and soil extraction with $1 \mathrm{M}$ $\mathrm{KCl}\left(1: 5 \mathrm{w} \mathrm{vol}^{-1}\right)$. Soil extracts were immediately frozen and later analyzed for nitrate $\left(\mathrm{NO}_{3}\right)$ and ammonium $\left(\mathrm{NH}_{4}\right)$ with aBran+Luebbe AutoAnalyzer 3 System (Bran+Luebbe, Norderstedt, Germany). In the field, soil temperature at 2 and $10 \mathrm{~cm}$ depths (Pt-100, Risø National Laboratory, Denmark) and soil volumetric moisture content at $10 \mathrm{~cm}$ (TDR, ThetaProbe ML2x, Delta-T) were measured continuously.

\subsection{Statistical analysis}

Difference between the daily mean fluxes measured by the automatic chamber and the EC were tested during one week period ( 7 to 14 May) when the automatic chamber was operated every three hours and hence produced up to eight measurements per day. Separate comparison of the daily mean EC data and the daily mean chamber data was conducted during two separate days, 7 and 15 May, when both automatic and manual chambers were operated. The EC data was sorted to night (22:00-08:00) and day-time (08:00-22:00) data, and separately to wind direction sectors each sector covering 45 degrees (see Fig. 1). The tests of significance of differences between mean fluxes were performed either using a parametric T-test for independent samples or a nonparametric Kruskal-Wallis test (SPSS 12.01, SPSS Inc.). The Pearson correlation analysis was used to test dependencies 
Table 1. Mean, median, minimum and maximum $\mathrm{N}_{2} \mathrm{O}$ emissions, and the coefficient of variation in the daily averaged eddy covariance (EC), automatic chamber and manual chamber measurements.

\begin{tabular}{lcccccc}
\hline Method & \multicolumn{3}{c}{$\mathrm{N}_{2} \mathrm{O}$ flux $\mu \mathrm{g} \mathrm{N} \mathrm{m}^{-2} \mathrm{~h}^{-1}$} & $\mathrm{CV}^{\mathrm{a}}$, & $\mathrm{CV} \%$, \\
& Mean & Median & Min & Max & daily $^{\mathrm{b}}$ & whole period $^{\mathrm{c}}$ \\
\hline EC daily mean & 5.3 & 4.2 & -0.8 & 20.3 & 310 & 257 \\
Auto chamber & 10.0 & 9.2 & 0.2 & 29.4 & 43 & 45 \\
Manual chambers & 16.0 & 8.4 & -4.3 & 93.5 & 138 & 148 \\
\hline
\end{tabular}

${ }^{\text {a }} \mathrm{CV} \%$, Coefficient of Variation $=($ stdev/mean $) 100 \%$

b Mean of all daily coefficients of variation. Daily CV\% for the EC includes 3-44 half-hourly flux values per day, automatic chamber includes 5-8 flux values per day (7-14 May), and manual chambers includes 7 flux values from the 7 chambers per day (6 manual chambers and 1 automatic chamber).

${ }^{\mathrm{c}}$ Mean of the CV\% over all measurements

between $\mathrm{N}_{2} \mathrm{O}$ fluxes and soil ammonium, nitrate and moisture contents.

\section{Results}

\subsection{The magnitude and variability of $\mathrm{N}_{2} \mathrm{O}$ emissions}

Average $\mathrm{N}_{2} \mathrm{O}$ emissions measured with the EC, automatic chamber and manual chambers during the measurement period 2 May-5 June were 5.6 $\pm 1.1,10 \pm 1$ and $16 \pm 11 \mu \mathrm{g} \mathrm{N} \mathrm{m}^{-2} \mathrm{~h}^{-1}$, respectively (Table 1 ). The $10 \%$ and $90 \%$ percentiles were -6.9 and $19.4 \mu \mathrm{g} \mathrm{N} \mathrm{m}^{-2} \mathrm{~h}^{-1}$ in the half hourly EC data, 6.0 and $15.0 \mu \mathrm{g} \mathrm{N} \mathrm{m}^{-2} \mathrm{~h}^{-1}$ in the automatic chamber data and -1.5 and $36.1 \mu \mathrm{g} \mathrm{N} \mathrm{m}^{-2} \mathrm{~h}^{-1}$ in the manual chamber data. Variation in $\mathrm{N}_{2} \mathrm{O}$ fluxes over the whole measurement period, expressed as coefficients of variation, was approximately six times higher in the EC data than in the automatic chamber data, and two times higher in the EC data than in the manual chamber data (Table 1). Most of the variation in the EC fluxes resulted from two factors: statistical uncertainty due to the use of a single measurement point and a rather short finite averaging period (Wilson and Meyers, 2001), and random instrumental errors as the fluxes were measured close to the detection limit.

Daily mean emissions measured by the EC were on average $9 \mu \mathrm{g} \mathrm{N} \mathrm{m}^{-2} \mathrm{~h}^{-1}$ during the first week of May and on average $4 \mu \mathrm{g} \mathrm{N} \mathrm{m}^{-2} \mathrm{~h}^{-1}$ during the rest of the campaign (Fig. 3a). The highest daily $\mathrm{N}_{2} \mathrm{O}$ emission to $20 \mu \mathrm{g} \mathrm{N} \mathrm{m}^{-2} \mathrm{~h}^{-1}$ were measured on the first measurement day, 2 May (Fig. 3a). Low fluxes were measured between 14 and 24 May after which the emissions peaked again on 25 and 31 May at $8 \mu \mathrm{g} \mathrm{N} \mathrm{m}^{-2} \mathrm{~h}^{-1}$. Short term variability in the fluxes measured by the EC system, expressed as daily coefficient of variation, was on average $400 \%$ during the first half of the measurement period and on average $260 \%$ during the last half of the period. The change in the variation was largely due to the change in the TDL setting on 10 May.
Temporal variability in the automatic chamber measurements was smaller than that of the EC measurements. The daily coefficient of variation in the automatic chamber data was on average $26 \%$ during 7 to 14 May and on average $50 \%$ thereafter. $\mathrm{N}_{2} \mathrm{O}$ emissions measured by the automatic chamber peaked on 12, 18, 25 and 28 May with a maximum daily emission of $17.7 \mu \mathrm{g} \mathrm{N} \mathrm{m}^{-2} \mathrm{~h}^{-1}$ on 28 May (Fig. 3b). The emissions with manual soil chambers ranged from small negative fluxes to the maximum of $93.4 \mu \mathrm{g} \mathrm{N} \mathrm{m}^{-2} \mathrm{~h}^{-1}$ on 7 May. Spatial variability between the chambers was higher than the temporal variability within the chambers. The temporal coefficient of variation, calculated as the mean of the coefficients of variation for a single chamber, was $101 \%$, whereas the spatial coefficient of variation, calculated as the mean of daily coefficients of variation between the fluxes measured by different chambers, was $138 \%$ (Table 1 ). One out of six manual chambers gave constantly higher emission values than the other five. If the data from this "hot spot" soil chamber was excluded the average $\mathrm{N}_{2} \mathrm{O}$ emission over the whole measurement period was $7.7 \mu \mathrm{g} \mathrm{N} \mathrm{m}^{-2} \mathrm{~h}^{-1}$ instead of $16.0 \mu \mathrm{g} \mathrm{N} \mathrm{m}^{-2} \mathrm{~h}^{-1}$ from all the chambers.

Comparison of the EC and automatic chamber fluxes during 7 to 14 May shows that on three out of seven days, 7, 10 and 11 May, the fluxes from the automatic chamber were significantly higher than those from the EC measurements $(\mathrm{p}<0.05$, T-test). When the data from the automatic and manual chambers were combined, on 7 and 15 May, the chamber and EC fluxes did not differ significantly from each other $(\mathrm{p}=0.27-0.31)$.

There was no diurnal cycle in the $\mathrm{N}_{2} \mathrm{O}$ emissions measured by the EC or chamber techniques. Night-time (22:00-08:00) $\mathrm{N}_{2} \mathrm{O}$ emissions measured with the automatic chamber averaged to $9.5 \pm 1.1 \mu \mathrm{g} \mathrm{N} \mathrm{m}^{-2} \mathrm{~h}^{-1}$, and day-time (08:00-22:00) emissions to $10.4 \pm 1.3 \mu \mathrm{g} \mathrm{N} \mathrm{m}^{-2} \mathrm{~h}^{-1}$ (emission $\pm 2 \times \mathrm{SE}$ ). The EC night and day time fluxes averaged to $7.3 \pm 1.2$ and $5.1 \pm 2.2 \mu \mathrm{g} \mathrm{N} \mathrm{m}^{-2} \mathrm{~h}^{-1}$, respectively. The differences between night and day emissions were not statistically significant. Mean daily coefficient of variation of $43 \%$ in the 


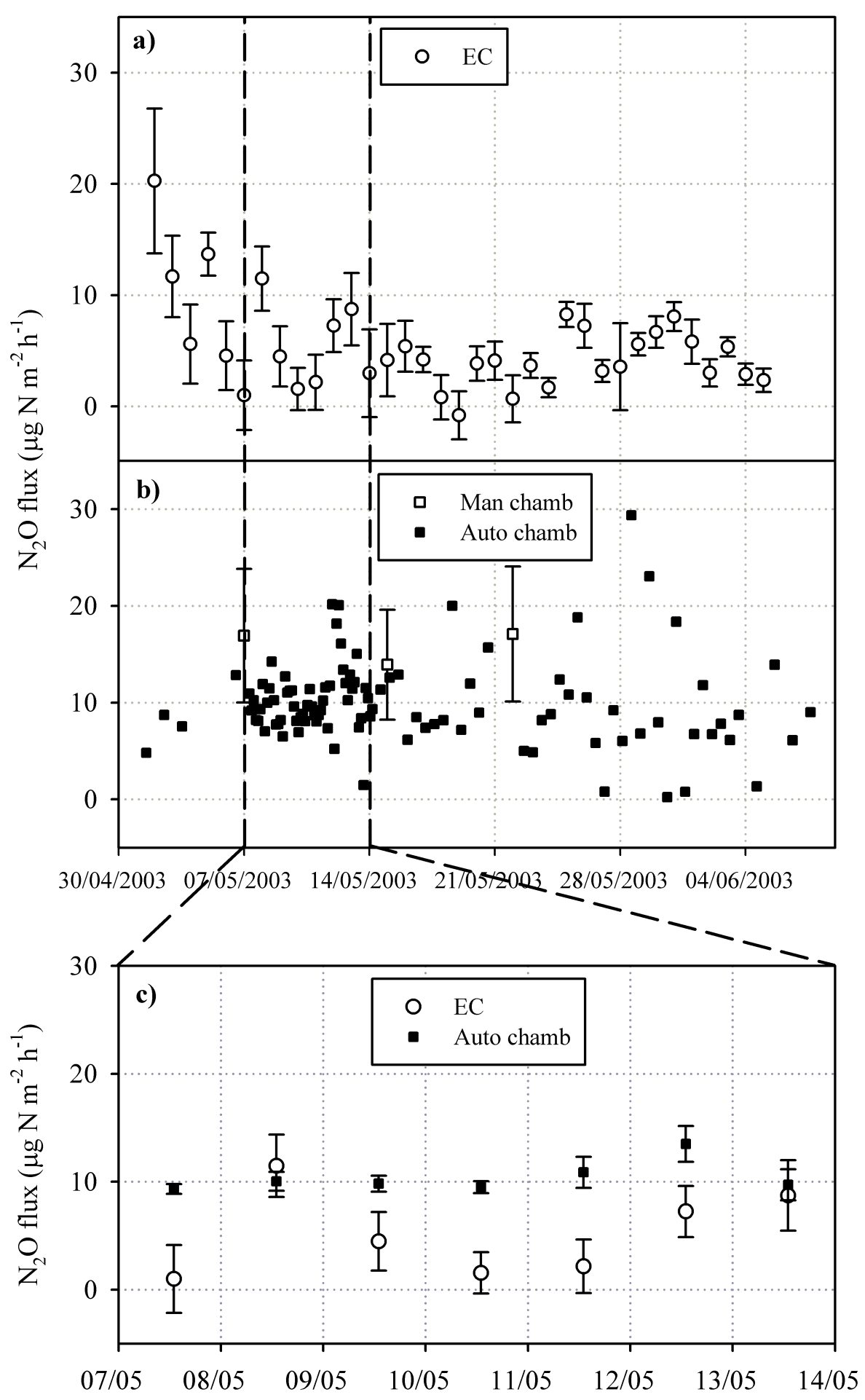

Fig. 3. Nitrous oxide emissions measured by eddy covariance (EC) and chamber techniques. (a) Open circles indicate EC daily mean $\mathrm{N}_{2} \mathrm{O}$ emissions \pm standard error of the mean $\left(\mathrm{n}_{E C}=3-44\right)$, (b) Closed squares stand for $\mathrm{N}_{2} \mathrm{O}$ emission measured by an automatic chamber, and open squares stand for $\mathrm{N}_{2} \mathrm{O}$ emissions measured by manual soil chamber. Error bars denote for $\pm \mathrm{SE}\left(\mathrm{n}_{\text {chambers }}=6\right)$, (c) Comparison of daily means of the $\mathrm{N}_{2} \mathrm{O}$ flux measured by the EC and the automatic chamber during 7 to 14 May. Error bars expresses $\pm S E$ ( $\mathrm{n}_{E C}=12-38$, $\mathrm{n}_{\text {chambers }}=5-8$ ), and $\mathrm{n}$ gives the number of measurements used for each mean calculation. 


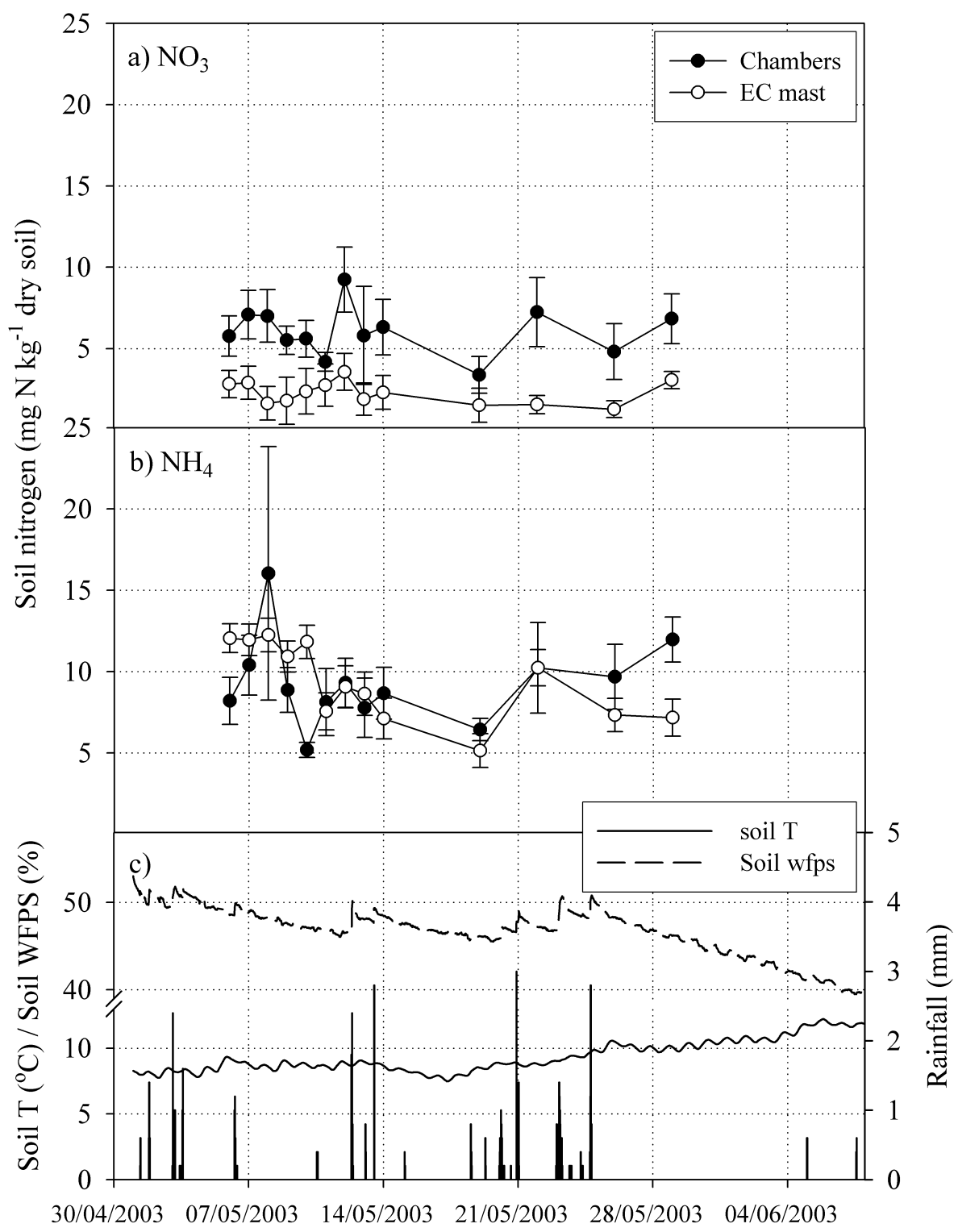

Fig. 4. Soil mineral nitrogen content at $0-10 \mathrm{~cm}$ depth of the soil from two areas: close to the soil chambers (black circles), and as an average over all the soil sampling places (open circles). (a) $\mathrm{NO}_{3}$, (b) $\mathrm{NH}_{4}$, (c) soil temperature at $10 \mathrm{~cm}$, soil moisture as percentage of water filled pore space (WFPS\%) at $0-6 \mathrm{~cm}$, and rainfall.

automatic chamber data indicates that the diurnal variability in the $\mathrm{N}_{2} \mathrm{O}$ emissions is very low at that chamber location (Table 1).

\subsection{Influence of soil environmental parameters on $\mathrm{N}_{2} \mathrm{O}$ emissions}

Soil nitrate $\left(\mathrm{NO}_{3}\right)$ content fluctuated very little during the measurement period (Fig. 4a). The two areas, close to the soil chambers and close to the EC mast, differed from each other with respect to soil $\mathrm{NO}_{3}$ content $(\mathrm{p}<0.01)$. In the area close to the chambers, $\mathrm{NO}_{3}$ content was on average 2.7 times higher than in the area close to the EC mast (Figs. 4a and b). Soil $\mathrm{NO}_{3}$ peaked on 12 May, after a rainfall event. The minimum $\mathrm{NO}_{3}$ content close to the chambers was measured on the same day as that of $\mathrm{NH}_{4}$ (19 May). Soil $\mathrm{NH}_{4}$ content during the measurement period was on average $9.3 \mathrm{mg} \mathrm{N}$ per $\mathrm{kg}$ of dry soil (Figs. 4a, b). Temporal variation in soil $\mathrm{NH}_{4}$ was larger than that of soil $\mathrm{NO}_{3}$. Soil $\mathrm{NH}_{4}$ content peaked on 8 May, decreased to a minimum on 19 May, and increased again at the end of May (Fig. 4b).

At the start of the measurement period, soil moisture and $\mathrm{NH}_{4}$ contents were at their maximum and soil temperature at its minimum (Figs. 4b and c). The decrease in soil moisture content throughout the measurement period was disrupted by 


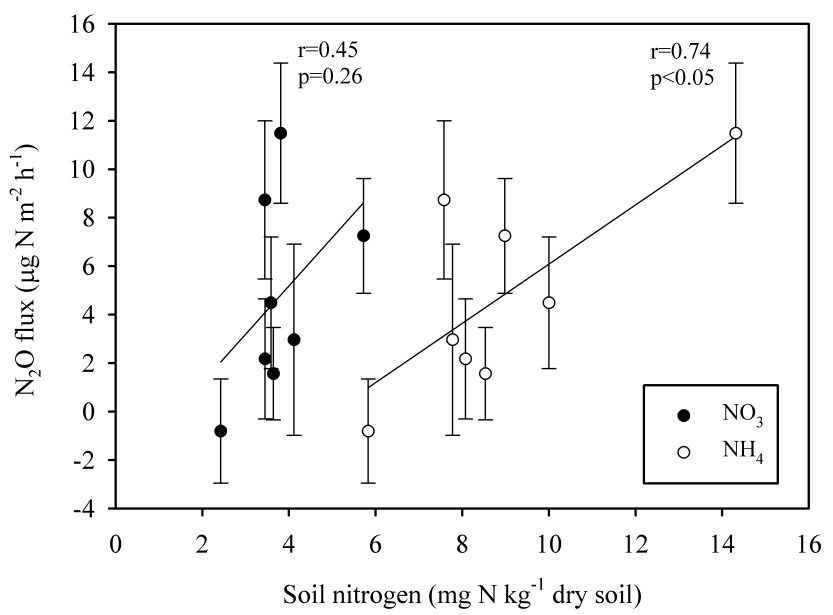

Fig. 5. Dependency of daily $\mathrm{N}_{2} \mathrm{O}$ emissions measured by the EC on soil mineral nitrogen $\left(\mathrm{NO}_{3}\right.$ and $\left.\mathrm{NH}_{4}\right)$ content during 8 to 19 May 2003.

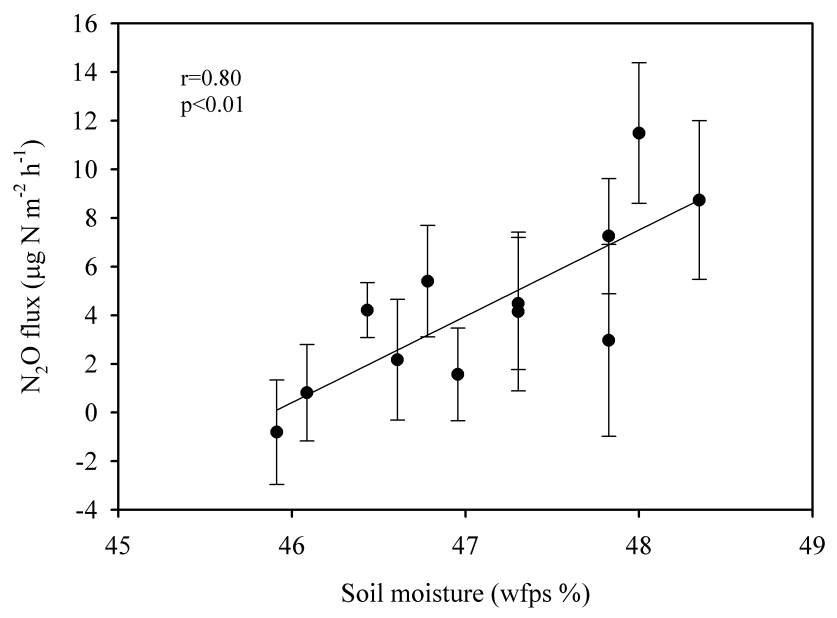

Fig. 6. Dependency of daily $\mathrm{N}_{2} \mathrm{O}$ emissions measured by the EC on soil moisture (wfps\%) during 8 to 19 May 2003.

several rainfall events. Soil surface temperature at $10 \mathrm{~cm}$ depth increased during the measurement period from approximately 7 degrees of Celsius to 12 degrees of Celsius (Fig. 4c). Fluctuations at the surface were greater than deeper in the soil (data not shown).

The $\mathrm{N}_{2} \mathrm{O}$ emissions measured with the $\mathrm{EC}$ technique followed the pattern of soil $\mathrm{NO}_{3}$ and $\mathrm{NH}_{4}$ contents (Figs. 3a and $4 a, b)$. Emissions of $\mathrm{N}_{2} \mathrm{O}$ correlated positively with soil $\mathrm{NH}_{4}$ content during a period 8 to 19 May $\left(\mathrm{r}^{2}=0.74, \mathrm{p}<0.05\right)$ (Fig. 5). The minimum $\mathrm{N}_{2} \mathrm{O}$ emission was measured on the same day, 19 May, as the minimum in soil $\mathrm{NO}_{3}$ and $\mathrm{NH}_{4}$ contents. The highest $\mathrm{N}_{2} \mathrm{O}$ emissions were measured on 2 May when soil moisture was at its highest (above 50\% wfps) (Figs. 3a and 4c). The emissions peaked on 13 and on 25 May after a rainfall and consequent increase in soil moisture. Soil $\mathrm{N}_{2} \mathrm{O}$ emissions correlated positively with soil moisture content from 8 to 19 May $\left(\mathrm{r}^{2}=0.80, \mathrm{p}<0.01\right)$ (Fig. 6).

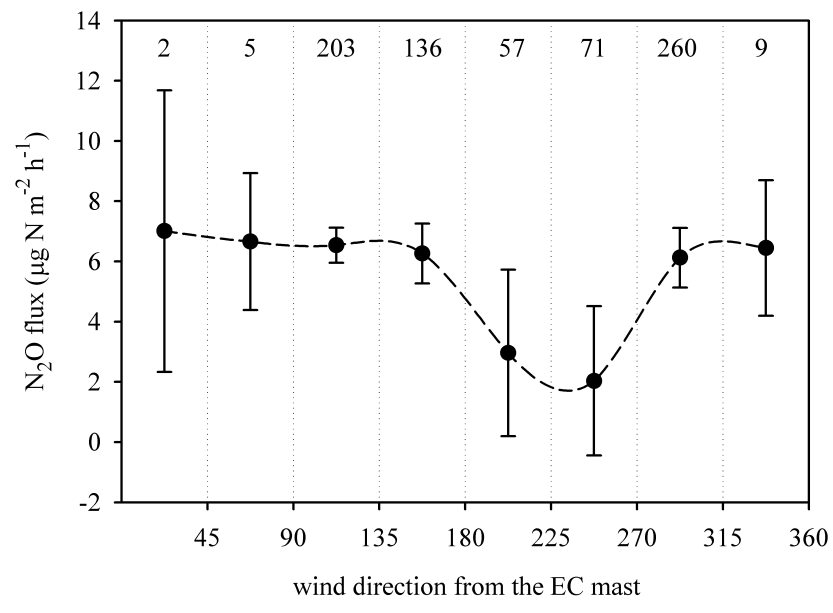

Fig. 7. Nitrous oxide emissions from different wind direction sectors from the eddy covariance (EC) measurement mast. Black dots represent the mean $\mathrm{N}_{2} \mathrm{O}$ emission from each of 45 degrees sector, error bars stand for \pm standard error of the mean $(n=2-260)$ and the dashed line is drawn to guide the eye of the reader. Numbers in the top of the figure stand for the number of data points from each wind sector.

\subsection{Wind direction dependency of $\mathrm{N}_{2} \mathrm{O}$ fluxes}

The average $\mathrm{N}_{2} \mathrm{O}$ flux was $2-4 \mu \mathrm{g} \mathrm{N} \mathrm{m}^{-2} \mathrm{~h}^{-1}$ from the south west direction and above $6 \mu \mathrm{g} \mathrm{N} \mathrm{m}^{-2} \mathrm{~h}^{-1}$ from all other wind directions (Fig. 7), however, this difference was statistically insignificant $(\mathrm{p}=0.49)$. Soil chambers were located north to north-west from the EC mast, a wind sector from which the EC measured a mean $\mathrm{N}_{2} \mathrm{O}$ emission of $6.4 \pm 2.2 \mu \mathrm{g} \mathrm{N} \mathrm{m}^{-2} \mathrm{~h}^{-1}$, mean $\pm \mathrm{SE}$ (Figs. 1 and 7). This flux value is less than the average emission of $15.0 \pm 4.9 \mu \mathrm{g} \mathrm{N} \mathrm{m}^{-2} \mathrm{~h}^{-1}$ measured by the soil chambers on 7, 15 and 22 May.

\section{Discussion}

We have shown that the chamber techniques and the EC technique deployed in the trunk-space give comparable estimates of the $\mathrm{N}_{2} \mathrm{O}$ fluxes. During the study period the spatial variability in the $\mathrm{N}_{2} \mathrm{O}$ emissions was greater than the temporal variability. The EC and the chamber fluxes did not differ significantly from each other except when the EC results were compared to the fluxes from the one automatic chamber only that exhibited a very small temporal coefficient of variation (45\%). Christensen et al. (1996) compared EC and chamber techniques to measure $\mathrm{N}_{2} \mathrm{O}$ emissions from an agricultural field. They measured 31 to $55 \%$ higher $\mathrm{N}_{2} \mathrm{O}$ emissions with the EC technique than with the soil chambers. Still, this difference between the two techniques was within the uncertainty given by the spatial variability of the flux over the measurement area. 
In general, we measured much higher variation in the $\mathrm{N}_{2} \mathrm{O}$ fluxes with the EC than with the chambers (Table 1). As the fluxes were close to the detection limit of the instrumentation, large part of the variation probably resulted from instrumental random errors in addition to the statistical sampling uncertainties (Wilson and Meyers, 2001). To decrease this variation and to lower the detection limit we averaged the half hourly flux values over one day periods. This allowed us to compare the low EC fluxes to the results from the chambers.

Other causes for the variation in the measured fluxes can be the real temporal and spatial variation in the $\mathrm{N}_{2} \mathrm{O}$ emissions. At times the soil may have acted as a sink for $\mathrm{N}_{2} \mathrm{O}$ as reported by Butterbach-Bahl et al. (1998), Goossens et al. (2001) and Rosenkranz et al. (2005). Indeed, we measured occasionally soil uptake of $\mathrm{N}_{2} \mathrm{O}$ with the manual soil chambers. The EC system, averaging fluxes over the footprint area, may have measured not only zero fluxes but also alternating $\mathrm{N}_{2} \mathrm{O}$ emissions and $\mathrm{N}_{2} \mathrm{O}$ uptake. An additional process, which may increase the variability in the $\mathrm{EC}$ data, is $\mathrm{N}_{2} \mathrm{O}$ emissions from the leaves of the forest trees reported recently by Pihlatie et al. (2005).

The loss of data during low turbulence periods such as night time has been one of the most negative characteristics of the EC method when measuring the exchange of $\mathrm{CO}_{2}$ and $\mathrm{H}_{2} \mathrm{O}$. Because we found no diurnal variation in the $\mathrm{N}_{2} \mathrm{O}$ emissions, measured by the automatic chamber, the lack of night time measurements does not bias the EC data in this study.

The highest $\mathrm{N}_{2} \mathrm{O}$ emissions measured with the EC were measured during the first week of May. This week was rainy and the soil moisture content was at its highest, above $50 \%$ of water filled pore space (wfps). In such conditions, anaerobic microsites may have been created in the soil increasing $\mathrm{N}_{2} \mathrm{O}$ production by denitrification. Another and parallel reason for higher fluxes during the first week may have been the micrometeorological conditions. As during the period when trees were leafing the requirements for sub-canopy micrometeorological measurements were better fulfilled than later on in the campaign: the canopy of the beech forest remained open and turbulence was more intense in the trunk-space. The beech trees were fully leafed in the middle of May after which also turbulence intensity decreased. A short increase in mean wind speed inside the trunk-space was measured during the last measurement week, in June (data not shown).

In previous studies, based on manual chamber measurements, the average annual $\mathrm{N}_{2} \mathrm{O}$ emissions from this beech forest floor was 5 to $6 \mu \mathrm{g} \mathrm{N} \mathrm{m}^{-2} \mathrm{~h}^{-1}$ (Ambus et al., 2001; Beier et al., 2001). Our spring time measurements of 6 to $16 \mu \mathrm{g} \mathrm{N} \mathrm{m}^{-2} \mathrm{~h}^{-1}$ with the EC and chambers, respectively, are in line with this, and also with other emission measurements from temperate forest soils (Schmidt et al., 1988; Ambus and Christensen, 1995; Bowden et al., 2000). In more detail, Beier et al. (2001) studied the total nitrogen cycling in this beech forest site. They found that the soil $\mathrm{NO}_{3}$ and $\mathrm{NH}_{4}$ contents were similar in areas close to and between tree stems indicating that the input of nitrogen to the forest floor via stemflow was insignificant to the soil pool of nitrogen. Similarly, Ambus et al. (2001) found no differences in the cumulative $\mathrm{N}_{2} \mathrm{O}$ emissions measured by chambers from two areas that differed from each other in soil moisture conditions. The results of Ambus et al. (2001) indicate that the ecosystem level variability in $\mathrm{N}_{2} \mathrm{O}$ emissions in this beech forest floor is relatively low and, hence, the soil chambers probably cover the spatial variability in the soil fluxes relatively well. In our study, however, the soil $\mathrm{NO}_{3}$ content varied between the two areas of the forest being higher in the area adjacent to the soil chambers than in the area close to the EC mast (Fig. 4a). As the soil chambers were located between 40 to $50 \mathrm{~m}$ from the EC mast they contribute less to the eddy flux than the closest tens of meters (Fig. 1). Hence, one reason for the lower $\mathrm{N}_{2} \mathrm{O}$ fluxes measured by the EC may be the lower levels of soil substrates, such as $\mathrm{NO}_{3}$, for microbial $\mathrm{N}_{2} \mathrm{O}$ production in the area surrounding the EC mast as compared to the area close to the chambers. The lack of soil chambers around the EC mast lowers the reliable comparison of the EC and the chamber based fluxes. Other factors affecting the comparison are the fact that wind blew only occasionally from the north-west direction where the chambers located, and that the EC fluxes were very close to the detection limit of the measurement system resulting in a large relative random uncertainty.

The placement of soil chambers is critical in covering the spatial variability of the soil $\mathrm{N}_{2} \mathrm{O}$ emissions if the data is used to estimate the ecosystem scale emissions. Since the spatial variability in this forest ecosystem was found to be greater than the temporal variability in the fluxes, the emphasis should be put on spatial coverage rather than high temporal resolution in the measurements. However, our results represent sites with a closed $\mathrm{N}$ cycling and low $\mathrm{N}_{2} \mathrm{O}$ emissions. In ecosystems with greater seasonal changes in the soil available nitrogen, the $\mathrm{N}_{2} \mathrm{O}$ pulses can contribute more significantly to the total $\mathrm{N}_{2} \mathrm{O}$ emissions and hence make temporal variation more important. Our results support the conclusions of Rummel et al. (2002) that the eddy covariance technique is a promising tool to measure $\mathrm{N}$ trace gas fluxes in the trunk-space of a forest. The EC technique used in this study can well be run continuously over extended periods, from several months to years requiring only filling with liquid nitrogen and routine checks twice a week. Thus, it can also give information on the seasonal variability in the $\mathrm{N}_{2} \mathrm{O}$ fluxes at ecosystem level.

\section{Conclusions}

We have demonstrated that the EC and the enclosure techniques give comparable results of the $\mathrm{N}_{2} \mathrm{O}$ emissions from a forest floor, although these techniques measure fluxes at 
different spatial and temporal scales. Measurements with the chamber technique show a large spatial small scale variation in the $\mathrm{N}_{2} \mathrm{O}$ fluxes, whereas the EC technique integrates over the areas of high and low $\mathrm{N}_{2} \mathrm{O}$ emissions from the soil. For a true comparison of the two techniques the methods should be applied in a forest ecosystem which has markedly higher $\mathrm{N}_{2} \mathrm{O}$ fluxes. The data suggests that if $\mathrm{N}_{2} \mathrm{O}$ emission measurements are based on chamber measurements only, the emphasis should be put on the placement of the soil chambers to cover the spatial variability in the soil $\mathrm{N}_{2} \mathrm{O}$ emission. For the estimation of ecosystem level $\mathrm{N}_{2} \mathrm{O}$ emissions the large scale integrative techniques, such as the EC technique, can be a substitutive technique to the enclosure method.

Acknowledgements. European Commission through the project NOFRETETE (EVK2-CT2001-00106), Magnus Ehrnrooth foundation, Nordic Centre of Excellence, Research Unit BACCI and the Finnish Academy financially supported this work. We would also like to thank T. Pohja, E. Siivola and P. T. Sørensen for technical assistance.

Edited by: F. X. Meixner

\section{References}

Ambus, P. and Christensen, S.: Spatial and seasonal nitrous oxide and methane fluxes in Danish forest-, grassland-, and agroecosystems, J. Environ. Qual., 24, 993-1001, 1995.

Ambus, P., Jensen, J. M., Priemé, A., Pilegaard, K., and Kjøller, A.: Assessment of $\mathrm{CH}_{4}$ and $\mathrm{N}_{2} \mathrm{O}$ fluxes in a Danish beech (Fagus sylvatica) forest and an adjacent $\mathrm{N}$-fertilised barley (Hordeum vulgare) field: effects of sewage sludge amendments, Nutr. Cycl. Agroecos., 60, 15-21, 2001.

Baldocchi, D. D. and Meyers, T. P.: Trace gas exchange above the floor of a deciduous forest 1 . Evaporation and $\mathrm{CO}_{2}$ efflux, J. Geophys. Res., 96(D4), 7271-7285, 1991.

Baldocchi, D. D.: Assessing the eddy covariance technique for evaluating carbon dioxide exchange rater of ecosystems: past, present and future, Global Change Biol., 9, 479-492, 2003.

Beier, C., Rasmussen, L., Pilegaard, K., Ambus, P., Mikkelsen, T., Jensen, N. O., Kjöller, A., Prieme, A., and Ladekarl, U. L.: Fluxes of $\mathrm{NO}_{3}^{-}, \mathrm{NH}_{4}^{+}, \mathrm{NO}, \mathrm{NO}_{2}$, and $\mathrm{N}_{2} \mathrm{O}$ in an old Danish beech forest, Water, Air and Soil Pollution: Focus 1: 187-195, 2001.

Bowden, R. D., Rullo, G., Stevens, G. R., and Steudler, P. A.: Soil fluxes of carbon dioxide, nitrous oxide, and methane at a productive temperate deciduous forest, J. Environ. Qual., 29, 268-276, 2000.

Butterbach-Bahl, K., Gasche, R., Huber, C. H., Kreutzer, K., and Papen, $\mathrm{H}$.: Inpact of $\mathrm{N}$-input by wet deposition on $\mathrm{N}$-trace gas fluxes and $\mathrm{CH}_{4}$-oxidation in spruce forest ecosystems of the temperate zone in Europe, Atmos. Environ., 32(3), 559-564, 1998.

Butterbach-Bahl, K., Rothe, A., and Papen, H.: Effect of tree distance on $\mathrm{N}_{2} \mathrm{O}$ and $\mathrm{CH}_{4}$-fluxes from soils in temperate forest ecosystems, Plant \& Soil, 240, 91-103, 2002.

Christensen, S., Ambus, P., Arah, J. R., Clayton, H., Galle, B., Griffith, D. W. T., Hargreaves, K. J., Klemedtsson, L., Lind, A.M., Maag, M., Scott, A., Skiba, U., Smith, K. A., Welling, M., and Wienhold, F. G.: Nitrous oxide emissions from an agricultural field: comparison between measurements by flux chamber and micrometeorological techniques, Atmos. Environ., 30(24), 4183-4190, 1996.

Constantin, J., Grelle, A., Ibrom, A., and Morgenstern, K.: Flux partitioning between understorey and overstorey in a boreal spruce/pine forest determined by the eddy covariance method, Agr. Forest Meteorol., 98-99, 629-643, 1999.

Ehhalt, D., Prather, M., Dentener, F., Derwent, R., Dlugokencky, E., Holland, E., Isaksen, I., Katima, J., Kirchhoff, V., Matson, P., Midgley, P., and Wang, M.: Atmospheric Chemistry and Greenhouse Gases, in: Climate Change 2001: The Scientific Basis, edited by: Houghton, J. T., Ding, Y., Griggs, D. J., et al., 2001 Cambridge University Press, Cambirdge, 881 pp, ISBN 052180767-0, 2001.

Goossens, A., De Visscher, A., Boeckz, P., and Van Cleemput, O.: Two-year field study on the emission of $\mathrm{N}_{2} \mathrm{O}$ from coarse and middle-textured Belgian soils with different land use, Nutr. Cycl. Agroecos., 60, 23-34, 2001.

Hutchinson, G. L. and Livingston, G. P.: Vents and seals in nonsteady-state chambers used for measuring gas exchange between soil and the atmosphere, European J. of Soil Sci., 52, 675-682, 2001.

Ishizuka, S., Iswandi, A., Nakajima, Y., Yonemura, L., Sudo, S., Tsuruta, H., and Muriyarso, D.: Spatial patterns of greenhouse gas emission in a tropical rainforest in Indonesia, Nutr. Cycl. Agroecos., 71(1), 55-62, 2005.

Launiainen, S., Rinne, J., Pumpanen, J., Kulmala, L., Kolari, P., Keronen, P., Siivola, S., Pohja, T., Hari, P., and Vesala, T.: Eddy covariance measurements of $\mathrm{CO}_{2}$ and sensible and latent heat fluxes during a full year in a boreal pine forest trunk-space, Bor. Env. Res., 10, 569-588, 2005.

Laurila, T., Tuovinen, J.-P., Lohila, A., Hatakka, J., Aurela, M., Thum, T., Pihlatie, M., Rinne, J., and Vesala, T.: Measuring methane emissions from a landfill using a cost-effective micrometeorological method, Geophys. Res. Lett., 32, 19, L19808, doi:10.1029/2005GL023462, 2005.

Laville, P., Hénault, C., Renault, P., Cellier, P., Oriol, A., Devis, X., Flura, D., and Germon, J. C.: Field comparison of nitrous oxide emission measurements using micrometeorological and chamber methods, Agronomie, 17, 375-388, 1997.

Massman, W. J. and Weil, J. C.: An analytical one-dimensional second-order closure model of turbulence statistics and the Lagrangian time scale within and above plant canopies of arbitrary structure, Boundary-Layer Meteorol., 91, 81-107, 1999.

Markkanen, T., Rannik, Ü., Marcolla, B., Cescatti, A., and Vesala, T.: Footprints and fetches for fluxes over forest canopies with varying structure and density, Boundary-Layer Meteorol., 106, 437-459, 2003.

Papen, H. and Butterbach-Bahl, K.: A 3-year continuous record of nitrogen trace gas fluxes from untreated and limed soil of a $\mathrm{N}$ saturated spruce and beech forest ecosystem in Germany $1 . \mathrm{N}_{2} \mathrm{O}$ emissions, J. Geophys. Res., 104(D15), 18 487-18 503, 1999.

Pihlatie, M., Ambus, P., Rinne, J., Pilegaard, K., and Vesala, T.: Plant-mediated nitrous oxide emissions from beech (Fagus sylvatica) leaves, New Phytol., 168, 93-98, 2005.

Pilegaard, K., Mikkelsen, T. N., Beier, C., Jensen, N. O., Ambus, P., and Ro-Poulsen, H.: Field measurements of atmospherebiosphere interactions in a Danish beech forest, Bor. Environ. 
Res., 8, 315-333, 2003.

Pumpanen, J., Kolari, P., Ilvesniemi, H., Minkkinen, K., Vesala, T., Niinistö, S., Lohila, A., Larmola, T., Morero, M., Pihlatie, M., Janssens, I., Curiel Yuste, J., Grünzweig, J. M., Reth, S., Subke, J.-A., Savage, K., Kutsch, W., Østreng, G., Ziegler, W., Anthoni, P., Lindroth, A., and Hari, P.: Comparison of different chamber techniques for measuring soil $\mathrm{CO}_{2}$ efflux, Agr. Forest Meteorol., 123, 159-176, 2003.

Rannik, Ü., Aubinet, M., Kurbanmuradov, O., Sabelfeld, K. K., Markkanen, T., and Vesala, T.: Footprint analysis for measurements over a heterogeneous forest, Boundary-Layer Meteorol., 97, 137-166, 2000.

Rosenkranz, P., Brüggemann, N., Papen, H., Xu, Z., Seufert, G., and Butterbach-Bahl, K.: $\mathrm{N}_{2} \mathrm{O}, \mathrm{NO}$ and $\mathrm{CH}_{4}$ exchange, and microbial $\mathrm{N}$ turnover over a Mediterranean pine forest soil, Biogeosciences Discuss., 2, 673-702, 2005,

SRef-ID: 1810-6285/bgd/2005-2-673.

Rummel, U., Ammann, C., Gut, A., Meixner, F. X., and Andreae, M. O.: Eddy covariance measurements of nitric oxide flux within an Amazonian rain forest, J. Geophys. Res., 107(D20), 8050, doi:10.1029/2001JD000520, 2002.

Savage, K. E. and Davidson, E. A.: A comparison of manual and automated systems for soil $\mathrm{CO}_{2}$ flux measurements: trade-offs between spatial and temporal resolution, J. Exp. Bot., 54(384), 891-899, 2003.

Schindlbacher, A., Zechmeister-Bolternstern, S., and ButterbachBahl K.: Effects of soil moisture and temperature on $\mathrm{NO}, \mathrm{NO}_{2}$, and $\mathrm{N}_{2} \mathrm{O}$ emissions from European forest ecosystems, J. Geophys. Res., 109, D17302, doi:10.1029/2004JD004590, 2004.

Schulte-Bisping, H. and Brumme, R.: Nitrous oxide emission inventory of German forest soils, J. Geophys. Res., 108(D4), 4132, doi:10.1029/2002JD002292, 2003.

Schmidt, J., Seiler, W., and Conrad, R.: Emission of nitrous oxide from temperate forest soils into the atmosphere, J. Atmos. Chem. 6, 95-115, 1988.

Silver, W. L., Thompson, A. W., McGroddy, M. E., Varner, R. K., Dias, J. D., Silva, H., Crill, P., and Kellers, M.: Fine root dynamics and trace gas fluxes in two lowland tropical forest soils, Global Change Biol., 11, 290-306, 2005.
Smith, K. A., Clayton, H., Arah, J. R. M., Christensen, S., Ambus, P., Fowler, D., Hargreaves, K. J., Skiba, U., Harris, G. W., Wienhold, F. G., Klemedtsson, L., and Galle, B.: Micrometeorological and chamber methods for measurement of nitrous oxide fluxes between soils and the atmosphere: Overview and conclusion, J. Geophys. Res., 99(D8), 16541-16548, 1994.

Tang, J., Baldocchi, D. D., and Xu, L.: Tree photosynthesis modulates soil respiration on a diurnal time scale, Global Change Biol., 11, 1298-1304, doi:10.1111/j.1365-2486.2005.00978.x, 2005.

Thomson, D. J.: Criteria for the selection of stochastic models of particle trajectories in turbulent flows, J. Fluid Mech., 180, 529556, 1987.

Tietema, A., Bouten, W., and Wartenbergh, P. E.: Nitrous oxide dynamics in an oak-beech forest ecosystem in the Netherlands, For. Ecol. Manage., 44, 53-61, 1991.

Weitz, A. M., Keller, M., Linder, E., and Crill, P. M.: Spatial and temporal variability of nitrogen oxide and methane fluxes from a fertilized tree plantation in Costa Rica, J Geophys. Res. 104(D23), 30 097-30 107, 1999.

Wienhold, F. G., Frahm, H., and Harris, G. W.: Measurements of $\mathrm{N}_{2} \mathrm{O}$ fluxes from fertilized grassland using a fast response tunable diode laser spectrometer, J. Geophys. Res., 99(D8), $16557-$ 16568, 1994.

Wilson, K. B. and Meyers, T. P.: The spatial variability of energy and carbon dioxide fluxes at the floor of a deciduous forest, Boundary-Layer Meteorol., 98, 443-473, 2001.

Yanai, J., Sawamoto, T., Oe, T., Kusa, K., Yamakawa, K. Sakamoto, K., Naganawa, T., Inubushi, K., Ryusuke, H., and Kosaki, T.: Spatial variability of nitrous oxide emissions and their soil-related determining factors in an agricultural field, J. Environ. Qual., 32, 1965-1977, 2003.

Yang, P. C., Black, T. A., Neumann, H. H., Novak, M. D., and Blanken, P. D.: Spatial and temporal variability of $\mathrm{CO}_{2}$ concentration and flux in a boreal aspen forest, J. Geophys. Res., 104(D22), 27 653-27 661, 1999. 